\title{
Bioanalysis
}

\section{Message from the editors}

\begin{abstract}
"More so now than ever, bioanalysis represents a hugely dynamic field, which we will endeavor to continue capturing in the journal."
\end{abstract}

Welcome to volume 7 of Bioanalysis! In this first issue of the new volume, we would like to take the opportunity to look back at the development of the journal since its launch in 2009, and how it has evolved alongside the field of bioanalysis.

Over the last 6 years, Bioanalysis has established itself as a platform for communication in the bioanalytical community. From reviews by leading experts to innovative research, the journal publishes a wide variety of high-quality articles in order to reflect the wealth of knowledge emerging from the field. The journal's 'double-blind' peer-review system is an integral pillar of our robust editorial process; this ensures that each article is evaluated solely on its scientific merit. In 2011, the publication frequency was increased from 12 to 24 issues per year in order to accommodate the growing interest in the journal, and in 2014 the journal was awarded an impact factor of 3.027 .

The field of bioanalysis has also evolved dramatically in recent years, as evidenced by the growth in the number of meetings where regulatory issues and developing trends are discussed. There has also been further expansion and refinement of technologies associated with small and large molecule measurement. More so now than ever, bioanalysis represents a hugely dynamic field, which we will endeavor to continue capturing in the journal.

\section{Key highlights}

Every year, Bioanalysis publishes a variety of articles covering key advances in the field. We have compiled a short list of some of the most accessed, highly cited and noteworthy papers throughout the past volumes
(Table 1). Of course, this is not an exhaustive list of highlights we have seen over the last 6 years, and we encourage you to explore the full back content. We would be keen to hear which papers you found most memorable.

\section{Special Focus Issues}

Our special focus issues aim to highlight the current themes in bioanalysis, from highly active fields of research to niche areas. Table 2 gives a list of the special issues published in 2013 and 2014; these sought to initiate a greater level of interest and awareness of the topics among a broader audience. We also have a number of exciting special issues planned for 2015, in which we will focus on radioisotopic bioanalysis, method transfer, stability assessment, ADCs, DBS analysis and LC-MS derivitization.

\section{Growth in unsolicited submissions}

Bioanalysis accepts a range of unsolicited manuscripts, including reviews, editorials and original research. Over the years we have seen an upwards trend in the number of submissions we receive. Of the total articles published in the journal, the percentage of unsolicited contributions increased from approximately $30 \%$ in 2013 to $40 \%$ in 2014 , demonstrating the high quality of the manuscripts submitted.

We understand the importance in publishing articles, particularly research papers, as soon as possible. We are therefore currently working towards implementing processes whereby articles will be published online first upon acceptance, ahead of the print issues - watch this space!

Since launching in 2009, we have also seen a steady growth in the number of research articles published, from 28 in 2009 to 88 in

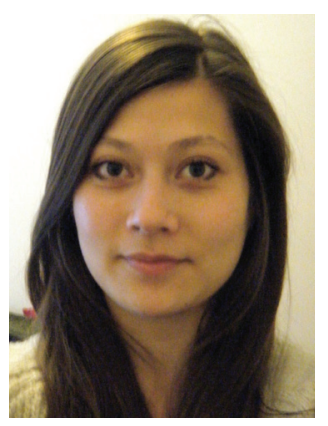

Kasumi Crews Author for correspondence: Future Science Ltd, Unitec House, 2 Albert Place, London, N3 1QB, UK k.crews@future-science.com

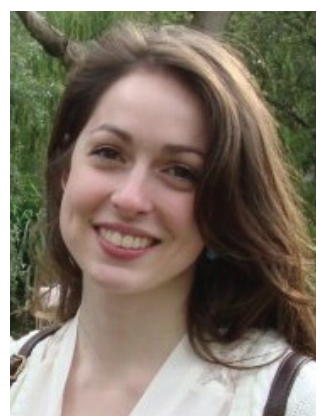

Bethany Small

Future Science Ltd, Unitec House, 2 Albert Place, London, N3 1QB, UK 
Table 1. Selection of key highlights from the journal.

\begin{tabular}{|c|c|c|c|c|}
\hline Title & Author(s) & Article type & Issue & Ref. \\
\hline $\begin{array}{l}\text { Anticoagulant counter ion impact on } \\
\text { bioanalytical LC-MS/MS assay performance: } \\
\text { additional validation required? }\end{array}$ & $\begin{array}{l}\text { Sennbro CJ, Knutsson } \\
\text { M, Timmerman P \& van } \\
\text { Amsterdam P }\end{array}$ & Editorial & Vol. 3, No. 21 & [1] \\
\hline $\begin{array}{l}\text { High-resolution mass spectrometry will } \\
\text { dramatically change our drug-discovery } \\
\text { bioanalysis procedures }\end{array}$ & Korfmacher W & Editorial & Vol. 3, No. 11 & [2] \\
\hline $\begin{array}{l}\text { European Medicines Agency guideline on } \\
\text { bioanalytical method validation: what more is } \\
\text { there to say? }\end{array}$ & Smith G & Commentary & Vol. 4, No. 8 & [3] \\
\hline $\begin{array}{l}\text { Comparison of triple quadrupole and high- } \\
\text { resolution TOF-MS for quantification of } \\
\text { peptides }\end{array}$ & $\begin{array}{l}\text { Dillen L, Cools W, Vereyken } \\
\text { L, Lorreyne W, Huybrechts } \\
\text { T, de Vries R, Ghobarah H } \\
\text { \& Cuyckens F }\end{array}$ & Research & Vol. 4, No. 5 & {$[4]$} \\
\hline $\begin{array}{l}\text { Capillary microsampling of } 25 \mu \mathrm{l} \text { blood for the } \\
\text { determination of toxicokinetic parameters in } \\
\text { regulatory studies in animals }\end{array}$ & $\begin{array}{l}\text { Jonsson O, Palma Villar R, } \\
\text { Nilsson LB, Norsten-Höög } \\
\text { C, Brogren J, Eriksson M, } \\
\text { Königsson K \& Samuelsson A }\end{array}$ & Research & Vol. 4, No. 6 & [5] \\
\hline $\begin{array}{l}\text { The effect of hematocrit and punch location } \\
\text { on assay bias during quantitative bioanalysis } \\
\text { of dried blood spot samples }\end{array}$ & $\begin{array}{l}\text { O'Mara M, Hudson-Curtis } \\
\text { B, Olson K, Yueh Y, Dunn J } \\
\text { \& Spooner N }\end{array}$ & Research & Vol. 3, No. 20 & [6] \\
\hline $\begin{array}{l}\text { Bioanalytical assay strategies for the } \\
\text { development of antibody-drug conjugate } \\
\text { biotherapeutics }\end{array}$ & $\begin{array}{l}\text { Kaur S, Xu K, Saad OM, Dere RC } \\
\text { \& Carrasco-Triguero M }\end{array}$ & Perspective & Vol. 5, No. 2 & [7] \\
\hline $\begin{array}{l}\text { Matrix effect elimination during LC-MS/MS } \\
\text { bioanalytical method development }\end{array}$ & $\begin{array}{l}\text { Côté C, Bergeron A, Mess JN, } \\
\text { Furtado M \& Garofolo F }\end{array}$ & Review & Vol. 1, No. 7 & [8] \\
\hline $\begin{array}{l}\text { Recent advances in metabolite identification } \\
\text { and quantitative bioanalysis by LC-Q-TOF MS }\end{array}$ & Xie C, Zhong D, Yu K \& Chen X & Review & Vol. 4, No. 8 & [9] \\
\hline $\begin{array}{l}\text { Bioanalytical approaches to analyzing } \\
\text { peptides and proteins by LC-MS/MS }\end{array}$ & Ewles M \& Goodwin L & Review & Vol. 3, No. 12 & [10] \\
\hline
\end{tabular}

2011, after the increase in publication frequency, and then to 103 in 2014.

If you are interested in submitting your work to us for consideration at any time, please do not hesitate to contact a member of our editorial team, or use our online submission system [23].

\section{Where do Bioanalysis readers \& authors come from?}

Bioanalysis has a wide reach, with both subscribers and authors based all around the globe. As shown in Figure $1 \mathrm{~A}$, the majority of subscribers are from Europe and North America (44 and 35\%, respectively); however, we have seen growth in the last few years in the number of subscriptions held in Asia and the rest of the world. As well as reaching readers worldwide, the journal also attracts readers from a variety of working environments (Figure 1B), with academic institutions making up around a third of subscriptions. As editors of Bioanalysis, we strive to work with scientists from both corporate and academic surroundings, as reflected in the type of organizations from which work is contributed. Volume 6 of the journal (2014) saw a similar number of publications from academic and corporate authors (42 and $47 \%$, respectively) (Table 3 ).

\section{Glossary}

In 2014 we worked closely with over 20 leading bioanalytical experts from industry and academia to develop the first edition of the Bioanalysis Glossary, which we hope will be regarded as an essential resource for bioanalysts. This guide will be particularly useful for those moving into the field or working with bioanalytical laboratories for the first time, and as a reference for experienced bioanalysts writing reports, research papers or presentations. Importantly, we hope this glossary will aid in harmonizing the terminology used by the bioanalytical community. The Bioanalysis Glossary is now available to download for free on our journal website [24]. 
Table 2. Special Focus Issues published in volumes 5-6.

\begin{tabular}{|c|c|c|c|}
\hline Topic & Guest Editor(s) & Issue & Ref. \\
\hline Bioanalysis of Biosimilars & Lakshmi Amaravadi \& Joseph Marini & Vol. 5, No. 5 & {$[11]$} \\
\hline ADCs & Surinder Kaur & Vol. 5, No. 9 & {$[12]$} \\
\hline HRMS & $\begin{array}{l}\text { Walter Korfmacher \& Ragu } \\
\text { Ramanathan }\end{array}$ & Vol. 5, No. 10 & {$[13]$} \\
\hline Increasing Productivity (Part I) & Howard Hill & Vol. 5, No. 13 & {$[14]$} \\
\hline Increasing Productivity (Part II) & Howard Hill & Vol. 5, No. 14 & {$[15]$} \\
\hline Matrix Effects & Annik Bergeron \& Fabio Garofolo & Vol. 5, No. 19 & {$[16]$} \\
\hline Tiered Approach & Philip Timmerman & Vol. 6, No. 5 & {$[17]$} \\
\hline Matrix Effects & Fabio Garofolo \& Binodh Desilva & Vol. 6, No. 8 & {$[18]$} \\
\hline Laboratory Management & Naidong Weng \& Qin C Ji & Vol. 6, No. 10 & {$[19]$} \\
\hline Systems Biology & Ian Wilson & Vol. 6, No. 19 & {$[20]$} \\
\hline Clinical Chemistry & N/A & Vol. 6, No. 21 & {$[21]$} \\
\hline Special Populations & $\begin{array}{l}\text { Peter van Amsterdam \& Margarete } \\
\text { Brudny-Kloeppel }\end{array}$ & Vol. 6, No. 23 & {$[22]$} \\
\hline
\end{tabular}

\section{Bioanalysis Zone}

Launched in March 2011, Bioanalysis Zone [25] is an interactive online resource for the bioanalytical community, building on the success of the journal and seeking to meet workflow needs and bring the community together. The site features the latest news relevant to those working within the bioanalytical field; articles from Bioanalysis; exclusive interviews and commentaries from opinion leaders working within academia and the pharmaceutical industry; exclusive webinars with a variety of experts; and a business directory. We also provide a forum for the community to discuss recent developments and pose any questions related to this fast-moving field. We are re-launching with an exciting new website in early 2015, with a revamped design and new features.

\section{Bioanalysis in the community}

The Bioanalysis editorial team has a keen interest in achieving a strong presence in the bioanalytical community through reaching out to our readers and contributors. Our aim in doing this is ensuring that Bioanalysis remains focused on key themes and trends. We are on social media, with a Bioanalysis LinkedIn group [26], providing followers with the latest journal news and updates, and a Twitter account (@fsgbio) [27] that provides updates on the latest and most interesting bioanalysis news and developments from the global community. You can also sign up for an electronic table of contents alert on our website [28], or contact our editorial team with feedback, suggestions, ideas, and of course unsolicited manuscript submissions or
(A)

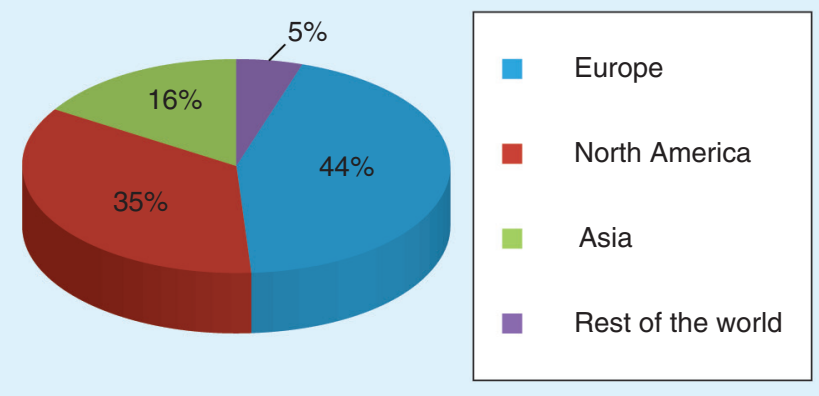

(B)

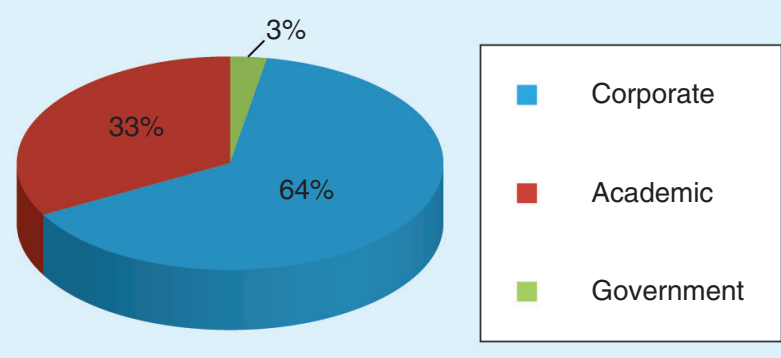

Figure 1. Percentage of subscriptions by location and sector. (A) Geographic location. (B) Sector. 
Table 3. Percentage of publications in volume 6 of Bioanalysis by authors' organization type.

\begin{tabular}{ll}
\hline Organization type & Percentage (\%) \\
\hline Corporate & 47 \\
\hline Academic & 42 \\
\hline Corporate and academic & 5 \\
\hline Government & 2 \\
\hline Government and academic & 1 \\
\hline Government and corporate & 1 \\
\hline Other & 2 \\
\hline
\end{tabular}

proposals. If you have not yet visited Bioanalysis Zone, we highly recommend you take a look around the site - it is a one-stop-shop of all things bioanalytical.

Lastly, we would like to recognize the support of our dedicated Senior Editors, Brian Booth and Neil

\section{References}

1 Sennbro CJ, Knutsson M, Timmerman P, van Amsterdam P. Anticoagulant counter ion impact on bioanalytical LC-MS/MS assay performance: additional validation required? Bioanalysis 3(21), 2389-2391 (2011).

2 Korfmacher W. High-resolution mass spectrometry will dramatically change our drug-discovery bioanalysis procedures. Bioanalysis 3(11), 1169-1171 (2011).

3 Smith G. European Medicines Agency guideline on bioanalytical method validation: what more is there to say? Bioanalysis 4(8), 865-868 (2012).

4 Dillen L, Cools W, Vereyken L et al. Comparison of triple quadrupole and high-resolution TOF-MS for quantification of peptides. Bioanalysis 4(5), 565-579 (2012).

5 Jonsson O, Palma Villar R, Nilsson LB et al. Capillary microsampling of $25 \mu \mathrm{l}$ blood for the determination of toxicokinetic parameters in regulatory studies in animals. Bioanalysis 4(6), 661-674 (2012).

6 O'Mara M, Hudson-Curtis B, Olson K, Yueh Y, Dunn J, Spooner N. The effect of hematocrit and punch location on assay bias during quantitative bioanalysis of dried blood spot samples. Bioanalysis 3(20), 2335-2347 (2011).

7 Kaur S, Xu K, Saad OM, Dere RC, Carrasco-Triguero $\mathrm{M}$. Bioanalytical assay strategies for the development of antibody-drug conjugate biotherapeutics. Bioanalysis 5(2), 201-226 (2013).

8 Côté C, Bergeron A, Mess JN, Furtado M, Garofolo F. Matrix effect elimination during LC-MS/MS bioanalytical method development. Bioanalysis 1(7) 1243-1257(2009).

9 Xie C, Zhong D, Yu K, Chen X. Recent advances in metabolite identification and quantitative bioanalysis by LC-Q-TOF MS. Bioanalysis 4(8), 937-959 (2012).

10 Ewles M, Goodwin L. Bioanalytical approaches to analyzing peptides and proteins by LC-MS/MS. Bioanalysis 3(12), 1379-1397 (2011)

11 Bioanalysis of Biosimilars. www.future-science.com/toc/bio/5/5
Spooner, without whom the growth of Bioanalysis would not have been possible. Neil took on the role in January 2014, when former Senior Editor Howard Hill stepped down after 5 years of invaluable guidance and input. We also extend our thanks to our other Editorial Board members, as well as the international community of authors and peer reviewers, and ever-expanding readership. We hope you enjoy volume 7 .

\section{Financial \& competing interests disclosure}

K Crews and B Small are employees of Future Science Group. The authors have no other relevant affiliations or financial involvement with any organization or entity with a financial interest in or financial conflict with the subject matter or materials discussed in the manuscript apart from those disclosed.

No writing assistance was utilized in the production of this manuscript.

12 ADCs.

www.future-science.com/toc/bio/5/9

13 HRMS. www.future-science.com/toc/bio/5/10

14 Increasing Productivity Part I. www.future-science.com/toc/bio/5/13

15 Increasing Productivity Part II. www.future-science.com/toc/bio/5/14

16 Matrix Effects. www.future-science.com/toc/bio/5/19

17 Tiered Approach. www.future-science.com/toc/bio/6/5

18 Matrix Effects. www.future-science.com/toc/bio/6/8

19 Laboratory Management www.future-science.com/toc/bio/6/10

20 Systems Biology. www.future-science.com/toc/bio/6/19

21 Clinical Chemistry. www.future-science.com/toc/bio/6/21

22 Special Populations. www.future-science.com/toc/bio/6/23

23 Future Science Online Submissions Portal. http://onlinesubmissions.future-science-group.com

24 Bioanalysis Journal Website. www.future-science.com/loi/bio

25 Bioanalysis Zone Website. www.bioanalysis-zone.com

26 Bioanalysis LinkedIn Group. www.linkedin.com/e/vgh/2819540

27 Bioanalysis Twitter Page. https://twitter.com/fsgbio

28 Future Science TOC Alert Services. www.future-science.com/action/showAlertSettings 